\title{
SHIFTING THE STANDARDISATION/ADAPTATION DEBATE TO NATIONAL FRANCHISING: EMPIRICAL EVIDENCE FROM GERMANY
}

\author{
Christof Backhaus, Ruhr-Universität Bochum, Germany \\ Markus Blut, TU Dortmund University, Germany \\ Tobias Heussler, Marketing Center Münster, Germany
}

\begin{abstract}
While the issue of standardisation versus adaptation has dominated the field of international marketing for the last few decades, it has been largely neglected in the area of domestic marketing, and especially in retailing. Yet, in franchise management, the standardization/adaptation dilemma remains one of the core challenges. However, while there is strong theoretical consensus in the literature on the issue, there is a lack of empirical research on standardization and adaptation in franchising. Against this background, the main objective of the paper is to gain insight into standardization in franchising and its potential effects on various performance outcomes. Specifically, the study investigates the following research questions: (1) What variables are critical to standardisation in franchising? (2) To what extent does the standardisation of such variables as pricing, uniqueness of the stores, or employee qualification convert into performance outcomes?
\end{abstract}

In accordance with the findings from the international marketing literature, a conceptual model is developed that is based on the assumption that the degree of standardization versus adaptation affects performance. It is suggested that standardisation issues determine consumer performance, franchisee performance, financial performance and market performance.

To test our conceptual model, we collected data from 61 franchise systems. The sample covered the following service areas: retailing (28.2\%), hotel and restaurant services $(6.7 \%)$, wholesale $(15.6 \%)$, and other services $(49.5 \%)$. The results of a regression analysis showed that - depending on the dimension of performance considered - standardisation can affect performance in a number of different ways. While pricing standardisation affects financial performance and franchisee performance negatively, it seems to be positively related to market performance. Furthermore, a positive impact of the standardisation of advertising and store appearance on financial and market performance was confirmed. The positive effect of advertising standardisation on franchisee performance might be related to the fact that franchisees expect centralized coordination and support of advertising, rather than taking responsibility for local advertising by themselves. The negative effect of standardising employee qualification on financial performance can be explained in terms of the relatively high costs of employee training measures.

In contrast to our hypotheses, the results of the study did not reveal a trade-off situation when optimizing standardization degrees in relation to different performance outcomes. Rather, standardization of store design, advertising and pricing did not point out be antagonistically related to economic performance (market performance and financial performance) on the one hand and franchisee performance on the other hand. Thus, the clear implication can be derived that further standardization of store design and advertising does not lead to performance losses in terms of franchisee performance. Similarly, further adaptation of pricing contributes to both economic performance and franchisee performance.

References available on request. 